\title{
EARLY EMBRYONIC DEATH AND SUBSEQUENT CYCLE LENGTH IN THE EWE
}

\author{
T. N. EDEY \\ Department of Livestock Husbandry, University of New England, \\ Armidale, N.S.W., Australia \\ (Received 13th April 1966)
}

Summary. Injections of colchicine into the lumen of the uterus of the ewe have been employed to cause timed embryonic deaths between Day 5 and Day 19 after ovulation. The length of oestrous cycles following embryonic death has then been studied.

Control ewes had a mean cycle length of $17.44 \pm 1.06$ days, and the cycle length of ewes treated on Days 5, 7,9 and 11 did not differ significantly from the controls. Ewes treated on Day 13 had a mean cycle length of $19 \cdot 75 \pm 0.90$ days, a highly significant increase over the controls. Embryonic death on Days 15 and 19 caused mean extensions of the cycle length of approximately 8 and 18 days respectively, but with wide individual variation.

The results are discussed in relation to the maintenance and regression of the corpus luteum in the presence of embryonic substance.

The findings indicate that in the field, embryonic death occurring on or before Day 11 is unlikely to be distinguished from fertilization failure.

\section{INTRODUCTION}

Delayed return to service in animals which experience early embryonic death has frequently been noted in cattle (e.g. Laing, 1949; Stewart, 1952; Stott \& Williams, 1962) and in sheep (Edey, 1965). Dutt (1963) suggested that, in sheep, deaths occurring after entry of the embryo into the uterus may cause extension of the cycle, while Edey (1966) obtained some evidence that, whereas embryonic death in the 1st week after mating resulted in return to service at the normal time, deaths occurring in the 2nd and 3rd weeks caused delayed returns.

It is known that in the ewe, in the absence of pregnancy, the corpus luteum starts to degenerate about the 14th day of the cycle (Warbritton, 1934). Where pregnancy supervenes, however, degeneration of the corpus luteum is prevented, the organ persisting to play its vital role in implantation and maintenance of pregnancy.

In their work on ova transfer in sheep, Moor \& Rowson (1964) have determined that, in the presence of an embryo, the 'signal' for maintenance of the corpus appears to be given on the 12th or 13th day of the cycle since removal of embryos from the uterus up to, but not beyond this time, results in cycles of normal length. 
As so little is known of the processes of embryonic death and resorption, and the size ranges of the embryo which may be critical in maintaining the corpus luteum, the question arises as to the time taken for an embryo dying on, say, Day 12, to be reduced below the critical size. Stewart (1952) has drawn attention to the possibility of corpora lutea persisting beyond the normal cycle length in the presence of degenerating embryonic material, but the extent to which degenerating material must be disposed of before a fresh ovulation can occur is unknown. Experiments designed to elucidate these points were therefore undertaken, and are reported in the present paper. Sheep were used and the direct approach of killing embryos in utero and studying subsequent returns to service has been employed.

The literature on the experimental killing of embryos for study of the subsequent degeneration of the conceptus has been reviewed by Brambell (1948) who reported that many of the techniques employed either resulted in abortion, or otherwise interfered grossly with the well-being of the mother. Of the methods reviewed by Brambell, the administration of colchicine was selected as the most suitable technique in the present work. This anti-mitotic substance has previously been used to cause embryonic death in mice (Kerr, 1947), in which animals suitable intramuscular doses caused death of the embryo and membranes within $12 \mathrm{hr}$. Kerr has described in detail the degenerative processes which follow death of the mouse embryo from colchicine, while the mode of action of the drug has been described by Levine (1948).

\section{METHODS AND MATERIALS}

A group of sixty mature Merino ewes was run with an infertile 'teaser' ram fitted with a harness and crayon (Radford, Watson \& Wood, 1960) to denote ewes served. Services were recorded at 09.00 hours and 17.00 hours daily. On being observed in oestrus, each ewe was hand-mated to two fertile Merino rams, and, if still in oestrus at the next observation, the ewe was mated again. On the basis of previous observations on duration of oestrus in these ewes, and knowledge that ovulation usually occurs during the latter part of oestrus (Asdell, 1946), an estimate of time of ovulation was made for each ewe.

At mating, the ewes were allocated to seven groups, each of seven animals. Within each group, four were treated with colchicine on a particular day after ovulation as follows: Group 1, Day 19; Group 2, Day 15; Group 3, Day 11; Group 4, Day 9; Group 5, Day 7; Group 6, Day 5; and Group 7, Day 13, respectively. In all except the Day 19 group the four ewes to be treated were selected randomly, and the remaining three went into a pooled control group. In the case of the Day 19 group, three of the seven ewes had returned to service before treatment. These three were allocated to the controls and the remaining four were treated with colchicine.

As results came to hand it became apparent that ovulation without oestrus might have occurred in two ewes in the Day 15 treatment group. It was therefore decided that a second group of ewes should be treated on Day 15, and then subjected to an exploratory laparotomy on Day 24 if return to service had not occurred (Group 8). 
The pooled control group provided an estimate of fertilization rate, while from the ewes which returned to service it also gave an estimate of the normal cycle length of the experimental ewes. Ewes which did not return to service were confirmed as pregnant by laparotomy (Lamond, 1963) about Day 35. The significance of differences between mean cycle length of control and individual treatment groups was assessed by $t$-test.

Preliminary work had shown that 0.2 to $0.3 \mathrm{mg}$ colchicine in $0.2 \mathrm{ml}$ distilled water injected into the lumen of the tubal end of the uterine horn rapidly killed the embryo without apparent ill-effects to the dam. Greater volumes of material injected, and injection into the body of the uterus were found to cause abortion of the conceptus in some cases. Direct injection into the uterus allowed the dose rate to be minimized, and the quantities used per ewe were similar to those given intramuscularly to mice by Kerr (1947) to kill embryos without other serious ill-effects on the dams.

On the appropriate number of days after the estimated time of ovulation, the ewes to be treated underwent mid-ventral laparotomy (Lamond, 1963), the reproductive tract was exteriorized and the number, location and condition of corpora lutea recorded. In ewes with one ovulation point only, $0.2 \mathrm{mg}$ colchicine was administered with a 22-gauge needle into the same side of the uterus as that on which the ovulation occurred. When there was a corpus luteum in each ovary, $0 \cdot 15 \mathrm{mg}$ colchicine was injected into each uterine horn.

Before and after treatment, all ewes (experimental and controls) were held in yards, fed at maintenance level, and run with an infertile 'teaser' ram fitted with a service marking crayon. Returns to service were recorded at 09.00 hours and 17.00 hours daily.

Arising from exploratory laparotomies and the slaughter of two ewes, some observations were made on regressive and degenerative processes in corpora lutea, uteri and embryos.

\section{Ovulation and fertilization rate}

\section{RESULTS}

Of thirty-three sheep in which ovulation points were counted, five $(15 \cdot 2 \%)$ had twin ovulations. The 20-day non-return rate of the control sheep, which would indicate the rate of fertilization minus the embryonic loss before Day 12, was $70 \%$.

\section{Cycle length of ewes}

Cycle lengths of individual sheep in each group together with group means and standard deviations (s.D.) and the significance of group differences are given in Table 1. These data show that in the control group, nine sheep returned to service with a mean cycle length of $17.44 \pm 1.06$ days and compared with these controls there was no significant deviation from normal in the cycle length of groups treated with colchicine on Days 5,7 and $9(15.38,17.50$ and 16.63 days respectively). The shorter cycle length of the Day 5 group was mainly due to the return of one ewe on Day 12. This ewe's next cycle was 18 days, but it is not thought likely that the 12-day cycle following colchicine treatment had any particular significance. The Day 11 group had a mean cycle 
length of $18.25 \pm 2.49$ which is not significantly different from the controls, but the group contained one ewe having a cycle length of 22 days. Whether this was a chance effect, or an indication that an extended cycle may result from treatment on Day 11 cannot be stated with certainty.

The Day 13 group had a mean cycle length of $19 \cdot 75 \pm 0.90$ days which was significantly longer $(P<0.01)$ than the controls. In the Day 13 group, one ewe which had not returned by Day 24 was subjected to an exploratory laparotomy. A recent ovulation point was found which was evaluated on the criteria of Dun, Ahmed \& Morrant (1960) and Restall (1964) as being not more than 3 days old. The cycle length of 21 days allotted to this ewe was considered to be minimal.

TABLE 1

TREATMENT AND GYGLE LENGTH DATA FOR INDIVIDUALS AND GROUPS

\begin{tabular}{|c|c|c|c|c|c|c|}
\hline Group & $\begin{array}{l}\text { Day of } \\
\text { treat- } \\
\text { ment }\end{array}$ & $\begin{array}{l}\text { No. of } \\
\text { sheep }\end{array}$ & $\begin{array}{l}\text { Individual cycle } \\
\text { lengths (days) }\end{array}$ & $\begin{array}{l}\text { Mean cycle } \\
\text { length and } \\
\text { S.D. (days) }\end{array}$ & $\begin{array}{l}\text { Significance of } \\
\text { difference from } \\
\text { controls }\end{array}$ & Remarks \\
\hline Controls* & & $\begin{array}{c}\text { Pregnant } \\
14 \text {; re- } \\
\text { turned } 9\end{array}$ & $\begin{array}{l}17,18,16,19,19 \\
17,18,16,17\end{array}$ & $17.44 \pm 1.06$ & & $\begin{array}{l}\text { *One ewe died on } \\
\text { Day } 10\end{array}$ \\
\hline 6 & 5 & 4 & $17,17.5,15,12$ & $15 \cdot 38 \pm 2 \cdot 16$ & $0.1>P>0.05$ & \\
\hline 5 & 7 & 4 & $17 \cdot 5,18 \cdot 5,18,16$ & $17.50 \pm 0.94$ & $P>0.09$ & \\
\hline 4 & 9 & 4 & $17,15,19,15 \cdot 5$ & $16 \cdot 63 \pm 1.56$ & $P>0.03$ & \\
\hline 3 & 11 & 4 & $16,16,22,19$ & $18 \cdot 25 \pm 2 \cdot 49$ & $P>0.04$ & \\
\hline 7 & 13 & 4 & $20,19 \cdot 5,18 \cdot 5,21^{*}$ & $19 \cdot 75 \pm 0.90$ & $P<0.01$ & $\begin{array}{l}\text { *Ovulation date } \\
\text { calculated at lap- } \\
\text { arotomy on Day } 24\end{array}$ \\
\hline 8 & 15 & 5 & $\begin{array}{l}32^{*}, 18,21,22 \\
\quad 33^{*}\end{array}$ & $25 \cdot 20 \pm 6 \cdot 06$ & $P<0.01$ & $\begin{array}{l}\text { *Exploratory lap- } \\
\text { arotomies perform- } \\
\text { ed on Day } 24\end{array}$ \\
\hline 2 & 15 & 4 & $40^{*}, 23,26,37 \dagger$ & $31 \cdot 50 \pm 7 \cdot 16$ & $P<0.001$ & $\begin{array}{l}\text { * Could be double } \\
\text { cycle } \\
\text { †Ovulation date } \\
\text { calculated at } \\
\text { slaughter on Day } \\
39\end{array}$ \\
\hline 1 & 19 & 4 & $31,36,30,46^{*}$ & $35 \cdot 75 \pm 6 \cdot 34$ & $P<0.001$ & $\begin{array}{l}\text { * Minimal figure; at } \\
\text { slaughter uterus } \\
\text { still contained } \\
\text { some embryonic } \\
\text { debris }\end{array}$ \\
\hline
\end{tabular}

Group 2 (treated on Day 15) contained two ewes having cycle lengths of 37 and 40 days respectively. The first of these ewes was slaughtered on Day 39, when the ovary contained an ovulation point estimated, on the criteria already mentioned, to be 2 days old. A cycle length of 37 days was therefore recorded for this ewe, and because of the presence of some necrotic embryonic material in the uterus at slaughter, this was considered to be a long cycle resulting from embryonic death on Day 15. In the case of the 40-day cycle, however, there was no exploratory laparotomy or slaughter to exclude the possibility that ovulation without heat had occurred about Day 23. This questionable 40-day cycle, then, may inflate the mean cycle length of $31 \cdot 5 \pm 7 \cdot 16$ days in this group, although there was clearly also a substantial extension of the cycle length of the other three sheep in the group. 
Group 8 (treated on Day 15) contained five treated sheep having a mean cycle length of $25.2 \pm 6.06$ days, representing a very highly significant increase over the controls. The range in this group was from 18 to 33 days. A better estimate of cycle length of ewes suffering embryonic death on Day 15 might be obtained by the exclusion of the 18-day cycle, on the grounds that it was probably a normal cycle following fertilization failure. If this were done the mean cycle length of the remaining four ewes would be $27 \cdot 0 \pm 5 \cdot 52$ days. In this group the two ewes having cycles of 32 and 33 days respectively were subjected to laparotomy on Day 24, which ruled out the occurrence of ovulation without oestrus. The Day 19 group contained three ewes which returned on Days 30, 31 and 36 respectively, and since the ovaries were inspected and the onset of pregnancy verified at the time of colchicine injection on Day 19, these clearly were single cycles. The fourth treated ewe was slaughtered when it had not returned to service by Day 46. Examination then confirmed that no silent ovulation had occurred and the ewe was included in the data as having a cycle length of 46 days. The mean of $35 \cdot 75 \pm 5 \cdot 12$ days for this group is therefore conservative.

TABLE 2

DATA ON COURSE OF DEGENERATIVE CHANGES

\begin{tabular}{|c|c|c|c|c|c|c|}
\hline $\begin{array}{l}\text { Ewe } \\
\text { No. }\end{array}$ & $\begin{array}{l}\text { Colchicine } \\
\text { treatment }\end{array}$ & $\begin{array}{l}\text { Exploratory } \\
\text { laparotomy }\end{array}$ & Observations & $\begin{array}{l}\text { Return to } \\
\text { service }\end{array}$ & Slaughter & Observations \\
\hline 15 & Day 15 & Day 24 & $\begin{array}{l}\text { Corpora lutea re- } \\
\text { gressing, uterus } \\
\text { pale and 'flabby' }\end{array}$ & Day 32 & & \\
\hline 89 & Day 15 & Day 24 & As for No. 15 & Day 33 & & \\
\hline 128 & Day 15 & Day 39 & $\begin{array}{l}\text { Fresh ovulation } \\
\text { point, about 2-days } \\
\text { old }\end{array}$ & & Day 39 & $\begin{array}{l}\text { Uterus contained } \\
\text { traces of degenerat- } \\
\text { ing embryonic } \\
\text { material }\end{array}$ \\
\hline 164 & Day 19 & Day 40 & $\begin{array}{l}\text { Corpus luteum re- } \\
\text { gressing, uterus } \\
\text { pale and of a size } \\
\text { consistent with } 20- \\
\text { days' pregnancy }\end{array}$ & & Day 46 & $\begin{array}{l}\text { Further regression } \\
\text { ion of corpus luteum } \\
\text { and uterus; con- } \\
\text { siderable volume of } \\
\text { embryonic material } \\
\text { in uterus }\end{array}$ \\
\hline
\end{tabular}

\section{Degenerative processes}

Exploratory laparotomies and the slaughter of two ewes yielded some information on the course of degeneration of corpora lutea, uteri and conceptuses. This is presented in Table 2.

\section{DISCUSSION}

The results of this experiment show that, in sheep, embryonic death occurring on or after Day 13 may cause extension of the normal oestrous cycle. This finding agrees with the conclusion of Moor \& Rowson (1964, 1966) that Day 12 or 13 is the critical time for initiation of the corpus luteum of pregnancy.

It appears reasonably certain that embryonic death following colchicine treatment on Day 11 did not cause an extension of the cycle. This is compatible with 
the idea that, following death, resorption of the very small amount of embryonic material present at this time would be rapid, and that the dead conceptus could not provide the luteotrophic stimulus necessary to prevent normal cyclical regression of the corpus luteum. At a later stage, however, corresponding to the Day-15 and Day-19 groups, for example, not only is the corpus luteum of pregnancy established, but the volume of embryonic material is more substantial, and the time needed for its resorption would be greater. During the resorption process, the embryonic substance apparently still has some luteotrophic effect since the mean time to ovulation, following colchicine treatment on Day 15 or Day 19, was 10.2 and 16.75 days respectively. Moor \& Rowson (1966) have suggested that to maintain the corpus luteum the embryo could act by a trigger mechanism stimulating further luteotrophic processes, or against a luteolytic principle from the uterus. Further work is planned on the regression of the corpus luteum of pregnancy during embryonic resorption.

The variation between animals in the return interval is also of interest in Groups 1 and 8 , and presumably is related, amongst other things, to the age at which embryonic death occurs. Thus, Kerr (1947) found that, in mice, the degenerative processes varied little between animals when death occurred at the 6 -day stage, but that at the 10-day stage the time taken for various changes to occur was much more variable. A reasonable parallel may be drawn between the mouse and the sheep since the mouse embryo at 10 days has a crown-rump length of about $3.5 \mathrm{~mm}$ (Kerr, 1947) which is similar to that in sheep at 15 days (Green \& Winters, 1945). Wide variation in oestrous cycle lengths was also found by Edey (1966) in ewes suffering embryonic mortality following under-nutrition in the 3rd week of pregnancy, but in this case the actual time of embryonic death could not be determined precisely.

It is possible that the presence of twin rather than single embryos could influence the rate of degeneration, but in the present experiment there were insufficient twin ovulators to give information on this point.

The finding in ewe No. 128 that embryonic debris did not prevent ovulation (though there was no oestrus) indicates that complete degeneration and resorption may not be necessary before the old corpus luteum can regress and a new ovulation occur. Presumably variation between sheep in circulating hormone levels would have an important influence on the time of reassertion of the oestrogenic phase following regression of the corpus luteum.

One of the most useful methods for diagnosing early embryonic death in farm animals is the detection of prolonged oestrous cycles. However, the present work indicates that embryonic deaths occurring on or before Day 11 will result in cycle lengths which are indistinguishable from those following fertilization failure.

\section{REFERENCES}

Asdell, S. A. (1946) Patterns of mammalian reproduction, p. 362. Constable, London. Brambell, F. W. R. (1948) Prenatal mortality in mammals. Biol. Rev. 23, 370.

Dun, R. B., Ahmed, W. \& Morrant, A. J. (1960) Annual reproductive rhythm in Merino sheep related to the choice of a mating time at Trangie, Central Western New South Wales. Aust. J. agric. Res. 11, 805. 
Dutr, R. H. (1963) Critical period for early embryo mortality in ewes exposed to high ambient temperature. F. Anim. Sci. 22, 713.

EDEY, T. N. (1965) Undernutrition and early embryonic mortality in Merino ewes. Nature, Lond. 208, 1232.

EDEY, T. N. (1966) Nutritional stress and pre-implantation embryonic mortality in Merino sheep. 7. agric. Sci. 67, 287.

Green, W. W. \& Winters, L. M. (1945) Prenatal development of the sheep. Tech. Bull. Minn. agric. Exp. Stn, No. 169.

KERR, T. (1947) On the effects of colchicine treatment of mouse embryos. Proc. zool. Soc. Lond. 116, 551.

LAING, J. A. (1949) Infertility in cattle associated with death of ova at early stages after fertilization. 7. comp. Path. 59, 97.

LAMOND, D. R. (1963) Diagnosis of early pregnancy in the ewe. Aust. vet. F. 39, 192.

Levine, M. (1948) The action of colchicine on cell division in human cancer, animal and plant tissues. Ann. N.Y. Acad. Sci. 51, 1365.

Moor, R. M. \& Rowson, L. E. A. (1964) Influence of embryo and uterus on luteal function in the sheep. Nature, Lond. 201, 522.

Moor, R. M. \& Rowson, L. E. A. (1966) The corpus luteum of the sheep: functional relationship between the embryo and the corpus luteum. F. Endocr. 34, 233.

Radford, H. M., Watson, R. H. \& Wood, G. F. (1960) A crayon and associated harness for the detection of mating under field conditions. Aust. vet. 7. 36, 57.

Restall, B. J. (1964) The growth and regression of the corpus luteum in the ewe. Aust. F. exp. Agric. Anim. Husb. 4, 274.

Stewart, D. L. (1952) The suppression of oestrus in dairy cattle after mating. Vet. Rec. 64, 303.

Sтотт, G. H. \& Williams, R. J. (1962) Causes of low breeding efficiency in dairy cattle associated with seasonal high temperatures. F. Dairy Sci. 45, 1369.

Warbritton, V. (1934) The cytology of the corpus luteum of the ewe. $\mathcal{7}$. Morph. 56, 181. 